\title{
Why we write (and how we can do it better)
}

Previously published at www.cmaj.ca ncreasingly, doctors are being encouraged to write about their personal experiences in clinical and academic settings. ${ }^{1}$ The aim of such exercises is usually stated: putting something down on paper will lead to reflection about the work we do, which in turn has the potential to foster empathy and improve patient care. There are numerous sections in journals (such as this one) and blogs, new medical literary magazines (such as the one I help to edit), international courses and workshops, all of which celebrate the promise of a new medical narratology. ${ }^{2}$

The usefulness of journaling, assembling portfolios and parallel charts and completing critical incident reports has been demonstrated with medical students and similar tasks are now being pursued with gusto by residents and graduate physicians in educational settings. Doctors in practice generally take up the pen (or tap on the keyboard) when confronting clinical uncertainty, processing powerful feelings, regrets and errors or when they (or a loved one) are facing personal illness. A few of them become famous in the process.

Writing narratives about specific clinical incidents honours the subjective experience of both doctor and patient. This is a welcome counterbalance to evidence-based practice, which emphasizes what is generalizable rather than what is unique, particular and unpredictable. We all agree that bringing story-telling back to medicine is what
I

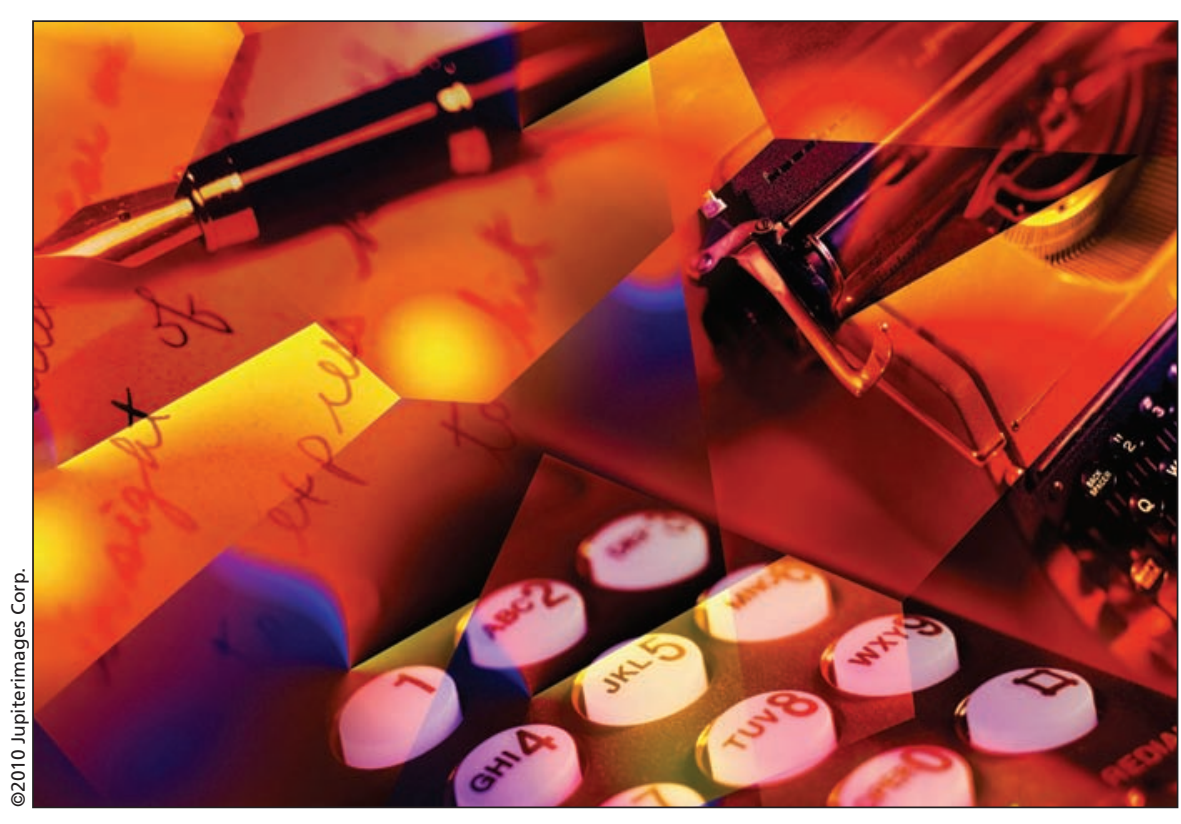

sis is an anti-narrative act, one which distills a lifetime into a single word or phrase. Stories, on the other hand, insist on meaning.

I have written throughout my career - most often for myself, as I try to make sense of my work, and sometimes for others, through publication. These two goals are very different, as is the motivation behind them.

For the last five years, I've helped to edit Ars Medica, a literary/medical humanities magazine, and have read hundreds of submissions. I've been forced to reflect on why doctors write, how and when we do it and whether there are mistakes we make as we go along. It occurs to me that this new wave of composition is not always honest, helpful or even benign. As educa-

\section{What are you trying to accomplish with this story? Does the ending ring true?}

we and our patients need. Our predecessors knew this and did not need to perform outcome research to prove it. The act of diagnosis abbreviates an illness experience, renders it manageable (or not), but seldom fleshes it out. Diagno- tors, policy-makers and clinicians, we should reflect on what writing and sharing stories means to us, how we approach the task and then contemplate what the risks are to our integrity as physicians. $^{3}$

\section{Five common errors}

I commonly see five errors that doctors make when they start writing. These observations begin with elements of craft and narrative competence, but then move into murkier territories of a particular brand of medical narcissism, hunger for publication and wobbly ethics. I'll summarize them briefly, then ask a question which I believe we should pose routinely to ourselves and to our colleagues whenever we share written stories about our patients.

1) Doctors have been taught to cut to the chase, so they usually do a lot of "telling" and not enough "showing" when they construct stories. Their narratives can be terse, pragmatic and mimic a case presentation rather than invite us into a new world. We need sounds, dialogue, colour, scents and images to enter the story. Readers, like patients, want to know that they are in good hands and that important things are not being missed.

Question: Why write this story about this patient and why now? Why do you care so much and why should we?

2) Doctors favour tidy endings, epiphanies and accounts of patients who exhibit courage and triumph over adversity. These have become the tropes of 
illness narratives, but they don't capture the chaos and suffering of medical practice or of real life. Readers want to be shaken and left with a challenge, dilemma or new take. Doctors sometimes use their writing to pat themselves on the back, celebrate successes or privilege narratives of people just like themselves. Such selective recounting and editing is seldom fully conscious or intentional. Stories about the disenfranchised and our clinical "failures" are much more honest and compelling. They are more difficult to write (and lead us to more unsettling reflection), but are more interesting to read and to leave a lasting impact.

Question: What am I trying to accomplish with this story? Does the ending ring true?

3) Doctors may forget whom they're writing for. Processing a personal dilemma or using writing as a reflective, therapeutic tool has great value, but that doesn't make the story comprehensible or even interesting to someone else. I've read a lot of submissions that were spontaneous and raw, but were not ushered through the exigencies of craft to the next level of becoming a real story. There was no reader in mind when the story was constructed; it was written for the physician-self. The piece may contain clichés, medical acronyms and excessive technical detail and assumes these fully set the stage. On the flipside, some of the most compelling stories we've received at our journal have been written by physicians who have to re-enter and re-imagine the medical world they once inhabited after falling ill themselves. ${ }^{4}$ Everything becomes new, foreign and menacing, and seen with new eyes. We as readers are taken on a journey.

Question: Whom is this story for: myself as learner, for a patient I wish to remember and honour, or for a literary reader who wants to be entertained and transported?

4) Neophyte physician writers may lack humility and patience. They are used to being right, calling the shots, seeing results and manifesting their authority. Many don't accept that they are beginners with respect to writing and that creative talent (and the muses themselves) simply won't be rushed. This reminds me of a story told by Margaret Laurence, a Canadian novelist and author of The Diviners. She was at a dinner party, sitting next to a neurosurgeon who, without guile, told her that he planned to write novels once he quit surgery. Without missing a beat, Laurence replied, "What a coincidence - when I stop writing, I plan to take up brain surgery." Lesson learned.

Question: Where am I in my writing and where do I need to go? Can I accept being a beginner who has lots to learn about a new craft?

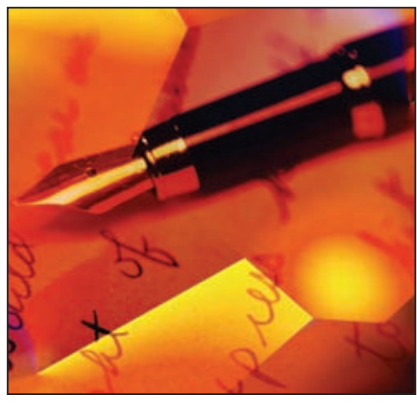

body identify this patient/clinical detail or story/family if they read my piece? If you have doubts that your writer's hat is taking precedence over your physician one, then you need to edit, revise, re-tell or get the opinion of a trusted colleague.

Part of physician grandiosity involves rationalizing that minor changes suffice to render the tale fictional or suggesting that "the patient will never read this anyway." Not so in a plugged-in, Internet world. (Not so in a litigious world either I've heard of doctors' personal reflection notes or parallel charts being subpoenaed as a part of a discovery for

5) The final common error is more serious and needs to be viewed through the lenses of ethics and professionalism. Doctors may think that stories heard in their offices belong to them. If they can be shared in case conferences, they can be published as memoir, poetry, essay or nudged into fiction (with merely the slightest of changes to identifying details). This notion is deeply flawed and suggests a conflict of interest. Stories are co-constructed and permission from the patient or his family must be sought out (and documented) if the medical encounter is to be morphed into a published form. (My own experience is that patients feel honoured that their story will be shared and may bene-

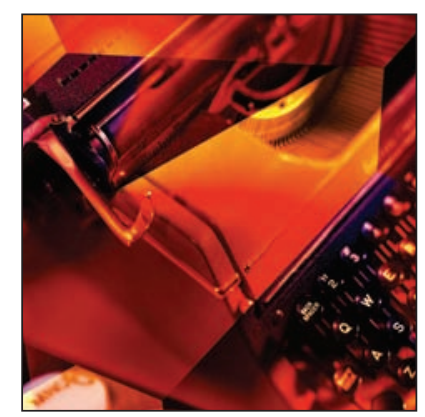
fit others. Some write rebuttals or parallel pieces. Some want certain details changed. Seldom do they refuse to have the story appear in print.) Fiction-writing physicians, if they are honest with themselves, can usually identify the impetus for a story - a singular image, facial expression or a patient's unique way of saying something. Part of craft is using that detail as a point of departure, then moving into something entirely new. You have to ask yourself, could any- litigation. Check your clinic's policy on where and how such notes should be kept, and whether their very existence should be referenced in the chart.)

Encouraging (or forcing) the sharing of stories among students and colleagues invites questions about boundaries, confidentiality, respect and potential stigmatization. Something can't be untold once it's out there. Pseudo-therapy is not the goal of this type of reflective writing, and the vulnerabilities of the teller and the maturity of the group must always be respected. (Writing is generally selfdosed in that people tell what they can or what they're ready for. Forcing premature closure or probing threads not yet conscious to the teller can do damage to both the story and its teller.)

Question: Whose story is this?

Finally, I worry that we may come to use stories as a balm for what ails our profession. Band-aid narratives make us feel good about what we do. We publish them in faculty or hospital magazines (although some of these institutions embrace less than admirable practices). We placate, have our alterauthor-egos stroked, and are placated ourselves. Stories can also be about control (propaganda being the perfect example). Once we pay more attention to patient narratives, how will we select, shape, manipulate and edit them and to what end? It's not up to us to determine what they mean or influence how they end, even as we see the plot unfolding. 
Final Question: Writing and sharing stories has made me more reflective and narratively competent. How am I using this new skill? Is patient care being served $^{5}$ or is this more linked to physician control, entitlement and advancement for me as an aspiring author?

\section{Allan Peterkin MD \\ Adviser, Humanities \\ CMAJ}

Allan Peterkin is a founding editor of Ars Medica: A Journal of Medicine, The Arts and Humanities (www.ars-medica.ca).

\section{REFERENCES}

1. Charon R. Narrative and Medicine. $N$ Engl J Med 2004;350:862-4.

2. Hatem D, Rider EA. Sharing stories: narrative medicine in an evidence based world. Patient Educ Couns 2004;54:251-3.

3. Mann K, Gordon J, MacLeod A. Reflection and reflective practice in health professions education: a systematic review. Adv Health Sci Educ Theory Pract 2009; 14:595-621.

4. Pennebaker JW. Telling Stories: The Health Benefits of Narrative. Lit \& Med 2000;19:3-18.

5. Zuger A. Doctors who wield the pen to heal the profession. The New York Times. 2007 May 15.

\section{More Humanities reading at www.cmaj.ca}

\section{Books}

\section{A Thousand Dreams: Vancouver's Downtown} Eastside and the Fight for its Future, by Larry Campbell, Lori Culbert and Neil Boyd (Greystone Books; 2009). This informal history of Vancouver, British Columbia's beleaguered Downtown Eastside, is more political memoir than data-driven analysis. Coauthored by a criminologist, Vancouver's former coroner and mayor, and a reporter from the Vancouver Sun, the story focuses on the efforts of heroes fighting against many different opponents, including psychoactive drugs, homelessness and commercial development. The

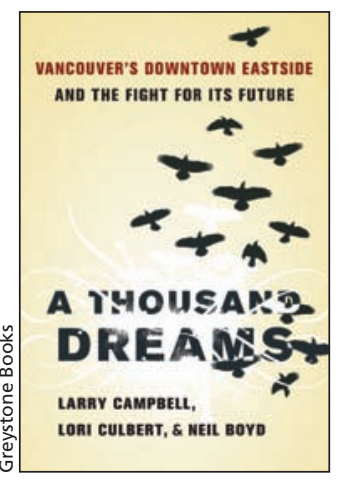
authors provide considerable insight into multiple urban health problems and the resilience of urban communities. Don C. Des Jarlais PhD, New York City, USA

\section{Poetry}

At the window, by Wynne Morrison MD, Philadelphia, USA

\section{Association médicale canadienne}

\section{Canadian Medical Association}

2011 Special Awards - Call for Nominations

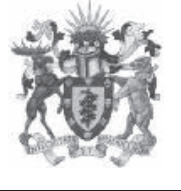

Prix spéciaux pour l'an 2011 - Appel de candidatures

The Canadian Medical Association invites nominations for the 2011 special awards.

- Medal of Honour

- F.N.G. Starr Award

- Medal of Service

- May Cohen Award for Women Mentors

- Sir Charles Tupper Award for Political Action

- Award for Excellence in Health Promotion

- Award for Young Leaders

- Dr. William Marsden Award in Medical Ethics

- Physician Misericordia Award

Refer to the "Awards from CMA" section on cma.ca for detailed criteria on each of the awards or contact the awards co-ordinator at $800663-7336 \times 2243$.

Nominations should be submitted in writing to:

Chair, Committee on Archives and Awards

c/o Committee Co-ordinator

Corporate Affairs

Canadian Medical Association

1867 Alta Vista Dr.

Ottawa ON K1G 5 W8

Closing date for receipt of nominations is Nov. 30, 2010.
L'Association médicale canadienne sollicite des candidatures à ses prix spéciaux pour l'an 2011.

- Médaille d'honneur

- Prix F.N.G. Starr

- Médaille de service

- Prix May-Cohen pour femmes mentors

- Prix Sir-Charles-Tupper d'action politique

- Prix d'excellence en promotion de la santé

- Prix des jeunes chefs de fíle

- Prix Dr-William-Marsden d'éthique médicale

- Prix Misericordia des médecins

Voir «Prix et distinctions de l'AMC» sur le site amc.ca pour les critères détaillés de chaque prix ou contacter la coordonnatrice des prix au 800 663-7336, poste 2243.

Président, Comité des archives et des distinctions a/s Coordonnatrice des comités

Affaires générale

Association médicale canadienne

1867, promenade Alta Vista

Ottawa (Ontario) K1G 5W8

Les candidatures doivent être présentées au plus tard le 30 novembre 2010 .
Les candidatures doivent être soumises à la :

\section{ASSOCIATION PANADIAN \\ MÉDICALE \& MEDICAL \\ CANADIENNE \& ASSOCIATION}

